\title{
USE OF ANALYTICAL TECHNIQUES FOR DECISION MAKING IN SRI LANKAN MANUFACTURING COMPANIES
}

\author{
$R$ N Liyanage ${ }^{a *}$ and A S Kumarage ${ }^{b}$ \\ a,b Department of Transport and Logistics Management, University of Moratuwa, \\ Moratuwa, Sri Lanka \\ * Correspondence should be addressed to ruwaninisansalaliyanage@gmail.com
}

\begin{abstract}
Optimising the use of resources through scientific methods is critical for efficiency and accurate pricing in the logistics industry. Analytical techniques (AT) play a decisive role in providing such analytical solutions.

This paper explores the use of Analytical Techniques for decision making in the Sri Lankan manufacturing logistics industry through a survey of practices in leading companies in the manufacturing logistics industry. The questionnaire focused on the familiarity of ATs and their use in the different logistics operations. The research reviewed and classified the different AT's most widely used in solving common logistics problems (LP).

Closing the gap between the theory and practice of AT in the logistics industry was aimed at through this research, by offering areas in which the industry could successfully adopt appropriate ATs. In this respect, different ATs in seven selected logistics decisions, regularly made in manufacturing firms, were discussed. The current practice in ATs was captured by interviewing leading practitioners in the logistics industry, bringing together the reasons for these gaps and their suggestions for overcoming them.
\end{abstract}

The findings of the research could open up exciting areas for future research on optimisation using ATs in manufacturing logistics.

Keywords: Analytical techniques (AT), Optimisation, Forecasting, Problem-solving and Decision making, Logistics activities 


\section{INTRODUCTION}

There are several analytical techniques available to make appropriate decisions that optimise resource utility [1]. However, as logistics operations' complexity increases, the need for making accurate and efficient decisions in the manufacturing industry increases. There is less research to identify analytical techniques (AT) the industry prefers using in complex decision-making situations. The primary objective of this paper is to determine any gap between the availability of ATs and their adoption for decision-making by the manufacturing logistics industry in Sri Lanka. Three secondary objectives were formulated: (a) identify the current trend of AT practise within these manufacturing companies, (b) identify reasons for these trends, and (c) identify how the use of appropriate ATs can be encouraged.

\section{METHODOLOGY}

This research was conducted in three stages: comprehensive literature review, data collection, and data analysis. First, a comprehensive literature review identified globally available ATs used to make logistics management decisions in complex operations. Online journals, books, and websites were searched using the keyword's analytical techniques, freight logistics, distribution, optimisation, decision making, real-world logistics application, operations research, and logistics problems. In the second stage, a questionnaire was developed, based on the literature review, to gather data to understand the application of such ATs in the manufacturing sector in Sri Lanka. Leading companies in manufacturing logistics were the target group for the survey and collected mostly using an online survey with a few in-person interviews. The questionnaire included questions on the scale of using ATs for different applications on a Likert Scale. Other responses were obtained as multiple-choice questions, linear scale questions, and checkboxes. The questionnaire was distributed among executives and senior managers of companies dealing with logistics activities in different functional areas such as warehouse, transport, production, and distribution from the different databases available with trade chambers and professional bodies. A mix of random and convenient sampling methods was adopted to select the sample. From the 70 leading manufacturing companies in Sri Lanka to which the forms were sent, 37 responses were received, reflecting a response rate of $53 \%$. In addition to the online survey, face-to-face interviews were held with fifteen higher-level managers directly involved in planning and managing logistics operations to identify reasons behind the current user behaviour in the use of ATs in their companies. Eight manufacturing firms representing various product manufacturing industries, four logistics service providers, one logistics consulting firm, and one logistics system development company were included in this face-to- 
face interview. Moreover, a focus group interview was carried out with 20 postgraduate students from the MBA in Supply Chain Management program at the University of Moratuwa, Sri Lanka.

The reasons for selecting these interview groups were the following.

- Manufacturing firms: Includes logistics decision-makers in the manufacturing companies.

- Logistics service providers: Includes decision-makers of the logistics functions.

- Logistics consulting firms: Includes providers of different consulting services to manufacturing firms to optimise the performance of logistics functions.

- Logistics system development companies: Includes firms developing and supplying tools for logistics support, including ATs, to optimise the logistics functions.

- Focus group interview: Includes executives and managers having knowledge of ATs, engaged in logistics functions.

The data gathered was analysed using SPSS software in the third stage of the research. Analytical methods, including hypothesis testing and examination of descriptive statistics such as comparison of means, graphical analysis, and frequency analysis, were deployed. Descriptive statistics were used to extract results and their meanings from the analysis. Spearman's Correlation Test and Mann-Whitney Test were adopted in hypothesis testing. Content Analysis and Discourse Analysis were employed in examining the primary data collected through interviews and focus-group discussions. Data were transcribed, coded, and analysed using NVIVO software.

\section{LITERATURE REVIEW}

\subsection{Logistics in the manufacturing industry}

Manufacturing logistics refers to planning, implementing, and controlling the flow of goods, services, and related information to carry out manufacturing activities from the point of origin to the final customer [2].

\subsection{Types of Logistics Problems (LPs)}

Logistics activities can be divided into two main functions, physical distribution and materials management. Physical distribution refers to the range of activities taken in freight movement from manufacturing to the point of consumption. It includes handling goods, transportation services, transhipment and warehousing services, trade, wholesale, and retail. Transportation services ensure the mobility requirements of supply chains are met. Material management includes all activities in the 
manufacturing of goods at any stage during a supply chain, including production, marketing, planning, demand forecasting, purchasing, and inventory management [3]. This research focuses on using ATs to solve common LPs, such as location selection, transport mode choice, optimal reverse and forward logistics network selection, vehicle routing problem (VRP), demand forecasting, inventory management, and production planning.

\subsection{Types of Analytical Techniques (AT)}

Analytical techniques used to solve problems or make decisions using qualitative or quantitative data have been classified differently in literature. Aguezzoul [4], for instance, identified multi-criteria decision-making (MCDM) techniques, mathematical programming models, artificial intelligence, statistical approaches, and integrated approaches as techniques applicable in the performance measurement of 3PL service providers. MCDM is a methodological framework that selects the best solution from a finite set of alternatives evaluated using multiple criteria. The mathematical programming models optimise objective functions that include cost, performance and time, under a set of constraints. Artificial intelligence is used for integrating quantitative and qualitative historical data with human expertise for decision-making. Correlation methods are used to analyse data gathered from empirical studies. Combining two or more techniques to select a better solution is usually called an integrated approach [4].

The majority of the companies use two or three ATs simultaneously for greater effectiveness. MCDM techniques, such as Analytical Hierarchy Process (AHP), are often used with mathematical programming and Fuzzy sets, which Bellman and Zadeh introduced in the 1970s. MCDM techniques are a vital tool to represent uncertainty and imprecision [5]. Grey System Theory and Fuzzy Set Theory can be used to engage with the uncertainty of human subjective judgments [6]. Fuzzy numbers developed by Zadeh in 1965 [7] could improve accuracy in many real-world decisions [8].

A classification of operation research techniques was conducted by Semini in 2011, [1] listing close to 200 Operations Research (OR) methods used in the manufacturing logistics industry. The primary OR techniques identified herein are Optimisation (Mathematical Programming), Dynamic Programming, Network Models, Simulation, Decision Analysis, Inventory Theory, Queuing Theory, Game Theory, Markov Chains, and Forecasting.

Further, multi-objective algorithms are listed as methods to optimise several objectives simultaneously [9]. Multi-objective Programming, also known as Goal Programming, maximises or minimises two or more objective functions [1]. 
Most forecasting methods belong to mathematical programming and statistical approaches. However, research in forecasting techniques classifies them in different ways. A study by Ghiani et al [10] classified them as quantitative and qualitative methods, with the latter further divided as casual and time-series extrapolation. Table 1 summarises the possible use of forecasting techniques in each category[10].

Table 1: Possibility of Usage of Forecasting Techniques

\begin{tabular}{|c|c|}
\hline Category & Comparison \\
\hline $\begin{array}{l}\text { Quantitative } \\
\text { Casual }\end{array}$ & $\begin{array}{l}\text { - Difficult to implement, even for larger companies. } \\
\text { - Difficult to identify any causal variable having a strong } \\
\text { - Difficulion with future demands. } \\
\text { variable in time. } \\
\text { - In practice, only single or multiple regression is used for } \\
\text { logistics planning and control. }\end{array}$ \\
\hline $\begin{array}{l}\text { Quantitative Time- } \\
\text { series extrapolation }\end{array}$ & $\begin{array}{l}\text { - Easier to understand and explain. } \\
\text { - Winter's method can be used whenever there are a linear trend } \\
\text { and a seasonal effect. } \\
\text { - In a business context, complex forecasting procedures seldom } \\
\text { yield better results than simple ones. }\end{array}$ \\
\hline Qualitative & $\begin{array}{l}\text { - To estimate the influence of political or macro-economic } \\
\text { changes on an item demand. }\end{array}$ \\
\hline
\end{tabular}

A study by Wang et al. has discussed big data analytics of supply chain and logistics management and classified the techniques into statistical, simulation, and optimisation methods [11]. Table 2 summarises ATs used by different industries in solving logistics problems, while Table 3 categorises ATs based on the technique and approach used to make decisions.

Table 2: Case studies in used AT

\begin{tabular}{|l|l|l|l|}
\hline Ref. & Industry/ Company & Problem & Analytical Techniques \\
\hline$[12]$ & $\begin{array}{l}\text { Brinova Fastigheter AB, } \\
\text { Sweden }\end{array}$ & $\begin{array}{l}\text { To determine locations of } \\
\text { logistics hubs }\end{array}$ & AHP, Gravity model \\
\hline$[13]$ & $\begin{array}{l}\text { Logistics service provider } \\
\text { company }\end{array}$ & $\begin{array}{l}\text { Capacitated VRP for inbound } \\
\text { logistics }\end{array}$ & $\begin{array}{l}\text { An ant-colony simulation- } \\
\text { based optimisation }\end{array}$ \\
\hline$[14]$ & $\begin{array}{l}\text { Household appliances, } \\
\text { UAE }\end{array}$ & $\begin{array}{l}\text { A reverse logistics network } \\
\text { design }\end{array}$ & MILP \\
\hline$[15]$ & Supermarkets/ Brazil & Heterogeneous fleet VRP & Scatter search \\
\hline$[16]$ & Red meat industry & $\begin{array}{l}\text { Multi-period location- } \\
\text { inventory-routing problem }\end{array}$ & $\begin{array}{l}\text { A linear mixed-integer } \\
\text { programming model }\end{array}$ \\
\hline
\end{tabular}




\begin{tabular}{|c|c|c|c|}
\hline Ref. & Industry/ Company & Problem & Analytical Techniques \\
\hline [17] & Dairy company, Italy & $\begin{array}{l}\text { A milk collection problem with } \\
\text { incompatibility constraints }\end{array}$ & $\begin{array}{l}\text { Mathematical programming } \\
\text { and local search multi-start }\end{array}$ \\
\hline [18] & Electronic appliances & $\begin{array}{l}\text { To determine the best logistics } \\
\text { partnership strategy }\end{array}$ & ANP \\
\hline [19] & Chemical Company & $\begin{array}{l}\text { For logistics optimisation: from } \\
\text { the perspective of effective } \\
\text { distance }\end{array}$ & $\begin{array}{l}\text { A Physarum-inspired } \\
\text { algorithm }\end{array}$ \\
\hline [9] & $\begin{array}{l}\text { Logistics service provider } \\
\text { company }\end{array}$ & $\begin{array}{l}\text { To minimize inventory holding } \\
\text { and transportation cost }\end{array}$ & $\begin{array}{l}\text { A multi-objective particle } \\
\text { swarm optimisation } \\
\text { algorithm }\end{array}$ \\
\hline [5] & $\begin{array}{l}\text { Multinational } \\
\text { conglomerate company }\end{array}$ & $\begin{array}{l}\text { Evaluation of five proposed } \\
\text { locations for a logistic centre }\end{array}$ & $\begin{array}{l}\text { The Fuzzy-PROMETHEE } \\
\text { method }\end{array}$ \\
\hline [20] & $\begin{array}{l}\text { Furniture and Electronics } \\
\text { Industries / Canada }\end{array}$ & $\begin{array}{l}\text { Heterogeneous VRP with time } \\
\text { windows }\end{array}$ & $\begin{array}{l}\text { Class-Based Insertion } \\
\text { Heuristic. }\end{array}$ \\
\hline [21] & Biogas plant & $\begin{array}{l}\text { The best reverse logistics } \\
\text { network evaluation }\end{array}$ & MILP, AHP \\
\hline [22] & Medical Items & $\begin{array}{l}\text { To optimise the logistics for a } \\
\text { fleet of drones for timely } \\
\text { delivery }\end{array}$ & $\begin{array}{l}\text { An optimisation model using } \\
\text { mathematical formulation }\end{array}$ \\
\hline [6] & $\begin{array}{l}\text { Automobile - } \\
\text { manufacturing company }\end{array}$ & $\begin{array}{l}\text { To develop 3PL provider } \\
\text { selection criteria }\end{array}$ & $\begin{array}{l}\text { Grey system theory } \\
\text { DEMATEL method }\end{array}$ \\
\hline [23] & $\begin{array}{l}\text { Soft drinks/ Coca-Cola/ } \\
\text { USA }\end{array}$ & $\begin{array}{l}\text { Optimises vehicle routes for } \\
\text { efficient product delivery }\end{array}$ & $\begin{array}{l}\text { ORTEC software based on } \\
\text { savings and local search }\end{array}$ \\
\hline [24] & Olive oil/ Tunisia & Multi-constrained VRP & Branch-and-cut \\
\hline [25] & Furniture Company & $\begin{array}{l}\text { Selection of third-party } \\
\text { logistics providers }\end{array}$ & Integer programming: \\
\hline [26] & $\begin{array}{l}\text { Car parts manufacturing } \\
\text { company }\end{array}$ & $\begin{array}{l}\text { the selection of third-party } \\
\text { reverse logistics providers }\end{array}$ & $\begin{array}{l}\text { AHP, Fuzzy and grey } \\
\text { numbers }\end{array}$ \\
\hline [27] & Conglomerate company & $\begin{array}{l}\text { To select the most suitable site } \\
\text { for a logistic centre }\end{array}$ & ARAS-F method \\
\hline [8] & $\begin{array}{l}\text { Logistics service provider } \\
\text { company }\end{array}$ & $\begin{array}{l}\text { For examining the different } \\
\text { modes for transportation of } \\
\text { freight }\end{array}$ & $\begin{array}{l}\text { Fuzzy analytic network } \\
\text { process (ANP) method }\end{array}$ \\
\hline [28] & $\begin{array}{l}\text { The semiconductor } \\
\text { company, Taiwan }\end{array}$ & $\begin{array}{l}\text { To determine the } \\
\text { manufacturing and logistics } \\
\text { system design }\end{array}$ & DEMATEL \\
\hline [29] & Sports fashion & $\begin{array}{l}\text { To determine operations in } \\
\text { DCs based on distribution } \\
\text { strategy }\end{array}$ & AHP \\
\hline [30] & Conglomerate / China & Multi-type fleet VRP & Threshold tabu search \\
\hline [31] & Foods, Athens & The Pallet-Packing VRP & Tabu search and heuristic \\
\hline [32] & $\begin{array}{l}\text { Polyethene terephthalate } \\
\text { bottles }\end{array}$ & $\begin{array}{l}\text { Designing and solving a } \\
\text { reverse logistics network }\end{array}$ & $\begin{array}{l}\text { A mixed-integer linear } \\
\text { programming model }\end{array}$ \\
\hline
\end{tabular}


Table 3: Classification of Analytical Techniques

\begin{tabular}{|c|c|c|c|c|}
\hline \multicolumn{5}{|c|}{ Pure Mathematical programming } \\
\hline \multicolumn{3}{|c|}{$\begin{array}{l}\text { Linear programming } \\
\text { Nonlinear programming } \\
\text { Data Envelopment Analysis (DEA) }\end{array}$} & \multicolumn{2}{|c|}{$\begin{array}{l}\text { Mixed integer programming (MIP) } \\
\text { Stochastic programming } \\
\text { Total Cost of Ownership (TCO) }\end{array}$} \\
\hline \multicolumn{5}{|l|}{ MCDM } \\
\hline \multicolumn{3}{|c|}{$\begin{array}{ll}- & \text { PROMETHEE methods } \\
- & \text { Decision-Making Trial and E } \\
& \text { Laboratory (DEMATEL) } \\
- & \text { TOPSIS } \\
- & \text { Interpretive Structural Model } \\
\end{array}$} & $\begin{array}{ll}- & \text { ANP } \\
- & \text { AHP } \\
- & \text { Additi } \\
- & \text { Quality } \\
- & \text { Utility }\end{array}$ & $\begin{array}{l}\text { atio Assessment Method (Aras) } \\
\text { inction Deployment (QFD) } \\
\text { eory }\end{array}$ \\
\hline \multicolumn{5}{|c|}{ Statistical techniques } \\
\hline \multicolumn{3}{|c|}{$\begin{array}{l}\text { Correlation Method } \\
\text { Cluster Analysis }\end{array}$} & \multicolumn{2}{|c|}{$\begin{array}{l}\text { Binary Logit } \\
\text { Multinomial logit (MNL) }\end{array}$} \\
\hline \multicolumn{5}{|c|}{ Artificial intelligence } \\
\hline \multicolumn{3}{|c|}{$\begin{array}{l}\text { Case-Based Reasoning/ Rule-Based } \\
\text { Reasoning (CBR/RBR) } \\
\text { Data Mining }\end{array}$} & \multicolumn{2}{|c|}{$\begin{array}{l}\text { Artificial Neural Networks (ANN) } \\
\text { Inference Method }\end{array}$} \\
\hline \multicolumn{5}{|c|}{ Uncertain theory } \\
\hline \multicolumn{3}{|c|}{$\begin{array}{l}-\quad \text { Grey system theory } \\
-\quad \text { Fuzzy set theory }\end{array}$} & \multicolumn{2}{|c|}{ - $\quad$ Probability statistics } \\
\hline \multicolumn{5}{|l|}{ VRP Algorithms } \\
\hline Extract & \multicolumn{2}{|c|}{$\begin{array}{ll}- & \text { branch-and-bound } \\
- & \text { branch-and-cut }\end{array}$} & & - $\quad$ set-covering-based \\
\hline Heuristics & \multicolumn{3}{|c|}{$\begin{array}{ll}- & \text { Clark and Wright algorithm } \\
- & \text { Particle Swarm Optimisation (PSO) } \\
- & \text { Genetic algorithm }\end{array}$} & $\begin{array}{ll}- & \text { simulated Annealing } \\
- & \text { Tabu search } \\
- & \text { evolutionary strategies }\end{array}$ \\
\hline Metaheuristics & \multicolumn{3}{|c|}{$\begin{array}{ll}- & \text { Benders' decomposition } \\
- & \text { polyhedral approach }\end{array}$} & $\begin{array}{ll}- & \text { dynamic programming } \\
- & \text { column generation }\end{array}$ \\
\hline \multicolumn{5}{|c|}{ Forecasting techniques } \\
\hline \multirow[t]{2}{*}{$\begin{array}{l}\text { Quantitative } \\
\text { methods }\end{array}$} & Casual & \multicolumn{2}{|c|}{$\begin{array}{ll}- & \text { Regression } \\
- & \text { Econometric models } \\
- & \text { Input-Output models } \\
- & \text { Neural networks }\end{array}$} & $\begin{array}{ll}- & \text { Life-cycle analysis } \\
- & \text { Computer simulation } \\
\text { models }\end{array}$ \\
\hline & $\begin{array}{l}\text { Time series } \\
\text { extrapolation }\end{array}$ & \multicolumn{2}{|c|}{$\begin{array}{ll}- & \text { Elementary technique } \\
- & \text { Moving averages } \\
- & \text { Double moving average } \\
\text { method } \\
-\quad \text { Exponential smoothing } \\
\text { techniques (Brown } \\
\text { method) }\end{array}$} & $\begin{array}{ll}- & \text { Holt method } \\
- & \text { Winters method } \\
- & \text { Decomposition approach } \\
- & \text { Box-Jenkins method } \\
- & \text { Revised exponential } \\
& \text { smoothing method }\end{array}$ \\
\hline $\begin{array}{l}\text { Qualitative } \\
\text { methods }\end{array}$ & \multicolumn{2}{|c|}{$\begin{array}{ll}- & \text { Panel consensus method } \\
\text { - } & \text { Delphi method }\end{array}$} & \multicolumn{2}{|c|}{$\begin{array}{ll}- & \text { Salesforce assessment } \\
- & \text { Market research }\end{array}$} \\
\hline
\end{tabular}




\begin{tabular}{|l|l|}
\hline \multicolumn{2}{|l|}{ Accessibility measurement models } \\
\hline$-\quad$ Gravity method & $-\quad$ Utility-based method \\
\hline$\quad$ Cumulative opportunity method & $-\quad$ MCDM with mathematical approaches \\
\hline \multicolumn{2}{|l|}{ Integrated Approaches } \\
\hline$-\quad$ Fuzzy-MCDM models \\
\hline \multicolumn{2}{|l|}{ Multi-objective models / Goal programming } \\
\hline$-\quad$ Fuzzy multi-objective mathematical models \\
$-\quad$ Multi-Objective Particle Swarm Optimisation (MOPSO) Models \\
\hline
\end{tabular}

\subsection{Mapping of Typical ATs used for Solving Different LPs}

Table 4 shows the summary of ATs by logistic function to solve relevant LPs. Highlighted cells indicate the techniques applicable to make decisions or solve problems.

Table 4: Mapping of AT Usage in selected Literature for Solving LP

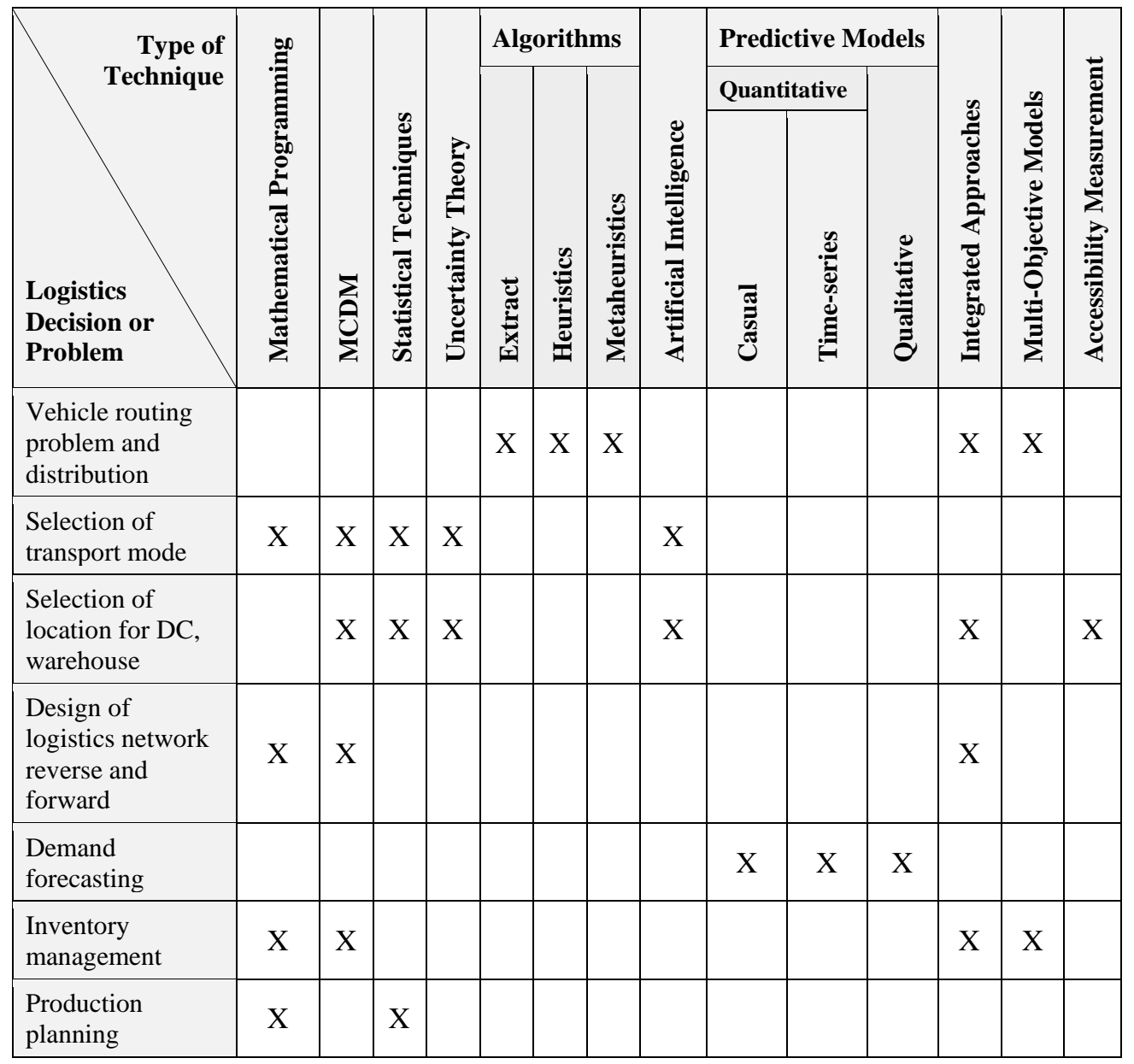




\subsection{Global trend of using analytical techniques}

With the prospect of Industry 4.0, companies focus on the principles of interconnectivity, digitalisation, and automation. Future research should focus on the field of artificial intelligence (AI), machine learning (ML), and deep learning (DL) in Smart Logistics [33].

A study conducted by Handfield et al. [34], using 62 interviews and 1757 international survey responses to observe the global logistics and supply chain trends revealed that introducing new technology by companies to increase the efficiency and effectiveness of logistics operations was a recognisable key trend. It also showed that respondents expected 30\% growth in new technology investments in RFID, inventory optimisation software, analytics, and big data technologies. Top performers were found applying Cost-to-Serve Analytics for making logistics decisions that provide optimum solutions to transport and logistics problems. More than $65 \%$ of respondents were planning to invest in network optimisation technologies such as inventory optimization software, transport management systems, advanced planning systems, and better data collection processes in the next five years (since 2013). About $60 \%$ of respondents had planned to invest in "Big Data" analytical tools within those five years [34] for forecasting, and other analyses would help organisations to optimise their logistics functions [35].

\section{RESULTS}

\subsection{Usage and Familiarity of ATs}

The hypothesis that "the usage of ATs is conditional to familiarity" was tested using the Likert scale responses to two questions in the questionnaire. Those questioned about usage and familiarity, on a scale of 1 to 4 . Table 5 shows that the p-value was less than 0.05 , indicating that the $\mathrm{H}_{0}$ would have to be rejected. It means data did not have normality. Therefore, it could be inferred that non-parametric tests would be necessary for testing this particular hypothesis. Spearman's correlation test was therefore used to determine the association between usage and familiarity.

Table 5: Tests of Normality

\begin{tabular}{|l|c|c|c|c|c|c|}
\hline \multirow{2}{*}{} & \multicolumn{4}{|c|}{ Kolmogorov-Smirnov $^{\text {a }}$} & \multicolumn{3}{c|}{ Shapiro-Wilk } \\
\cline { 2 - 7 } & Statistic & df & Sig. & Statistic & Df & Sig. \\
\hline Usage & 0.288 & 37 & 0.000 & 0.776 & 37 & 0.000 \\
\hline Familiarity & 0.399 & 37 & 0.000 & 0.689 & 37 & 0.000 \\
\hline a. Lilliefors Significance Correction \\
\hline
\end{tabular}


As shown in Table 6, though usage appeared to be lower than familiarity, no significant relationship between usage and familiarity could be found, as per Spearman's correlation test. The $\mathrm{H}_{0}$, that "there is no significant relationship between the variables", could be accepted because the p-value $(0.843)$ was greater than 0.05 .

Table 6: Spearman's Correlation

\begin{tabular}{|c|c|c|c|c|}
\hline & & & Usage & Familiarity \\
\hline \multirow{6}{*}{ Spearman's rho } & \multirow{3}{*}{ Usage } & Correlation Coefficient & 1.000 & 0.034 \\
\hline & & Sig. (2-tailed) & . & 0.843 \\
\hline & & $\mathrm{N}$ & 37 & 37 \\
\hline & \multirow{3}{*}{ Familiarity } & Correlation Coefficient & 0.034 & 1.000 \\
\hline & & Sig. (2-tailed) & 0.843 & \\
\hline & & $\mathrm{N}$ & 37 & 37 \\
\hline
\end{tabular}

It was observed that, while familiarity with AT should be a pre-condition for use, it would not always happen. As shown in Figure 1, the response to AT usage had a smaller mean than familiarity with AT. It seemed that sound familiarity would result in usage only half the time, but that too, only intermittently, while partial familiarity would lead mostly to intermittent use.

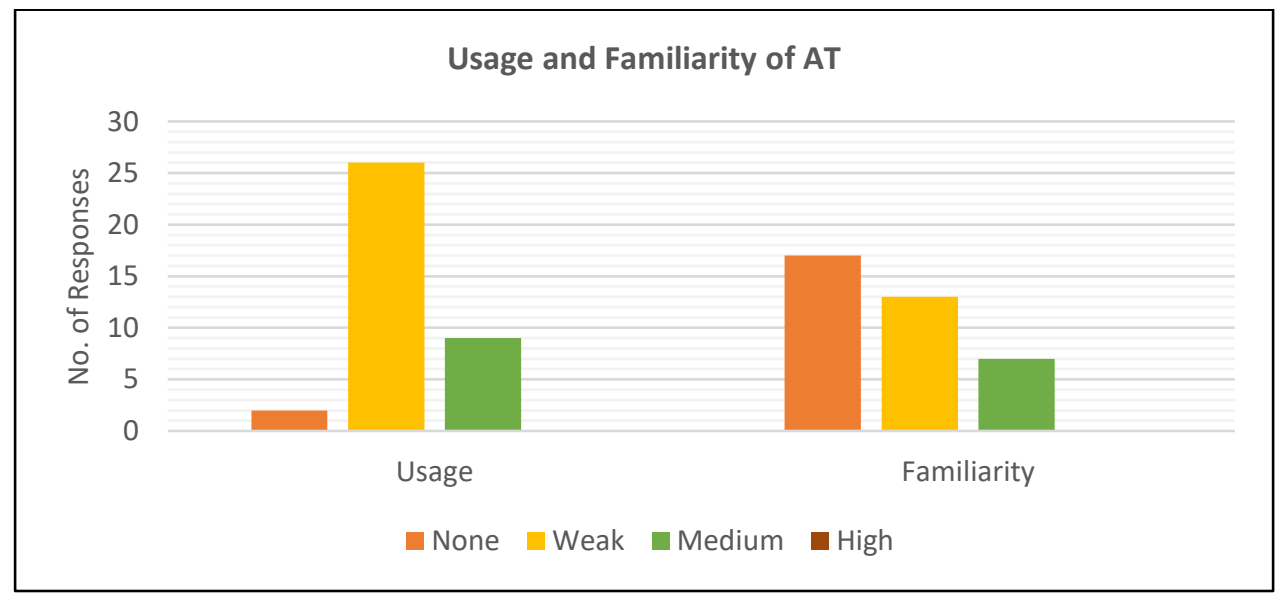

Figure 1: Distribution of Responses for Usage and Familiarity of AT

Further, as shown in Table 7, the mean (1.73) for usage is less than 2.0, which makes it evident that the usage of ATs is less than desired. 
Table 7: Descriptive statistics of Usage and Familiarity

\begin{tabular}{|l|r|r|r|r|r|r|r|}
\hline & $\mathbf{N}$ & Mean & $\begin{array}{r}\text { Std. } \\
\text { Deviation }\end{array}$ & \multicolumn{2}{|c|}{ Skewness } & \multicolumn{2}{|c|}{ Kurtosis } \\
\cline { 2 - 8 } & Statistic & Statistic & Statistic & Statistic & $\begin{array}{r}\text { Std. } \\
\text { Error }\end{array}$ & Statistic & $\begin{array}{r}\text { Std. } \\
\text { Error }\end{array}$ \\
\hline Usage & 37 & 1.73 & 0.769 & 0.516 & 0.388 & -1.100 & 0.759 \\
\hline Familiarity & 37 & 2.19 & 0.518 & 0.265 & 0.388 & 0.332 & 0.759 \\
\hline $\begin{array}{l}\text { Valid N } \\
\text { (listwise) }\end{array}$ & 37 & & & & & & \\
\hline
\end{tabular}

Figure 2 shows that only $29 \%$ were regularly using ATs, and $37 \%$ did not use ATs at all. ATs were mostly used for marketing, for example, demand forecasting, followed by inventory and production planning/procurement activities and logistics decisions. These activities were also tracked using ATs in ERP solutions. ATs for planning operational activities, such as Vehicle Routing Problem (VRP) or Location Selection, had a much lower incidence of use. In the logistics industry, selecting the best mode of transport appears to be handled mainly through experience rather than any ATs. Other functional areas, such as inventory management and production planning procedures, appeared to use ATs, most likely due to the technical characteristics of the functions involved.

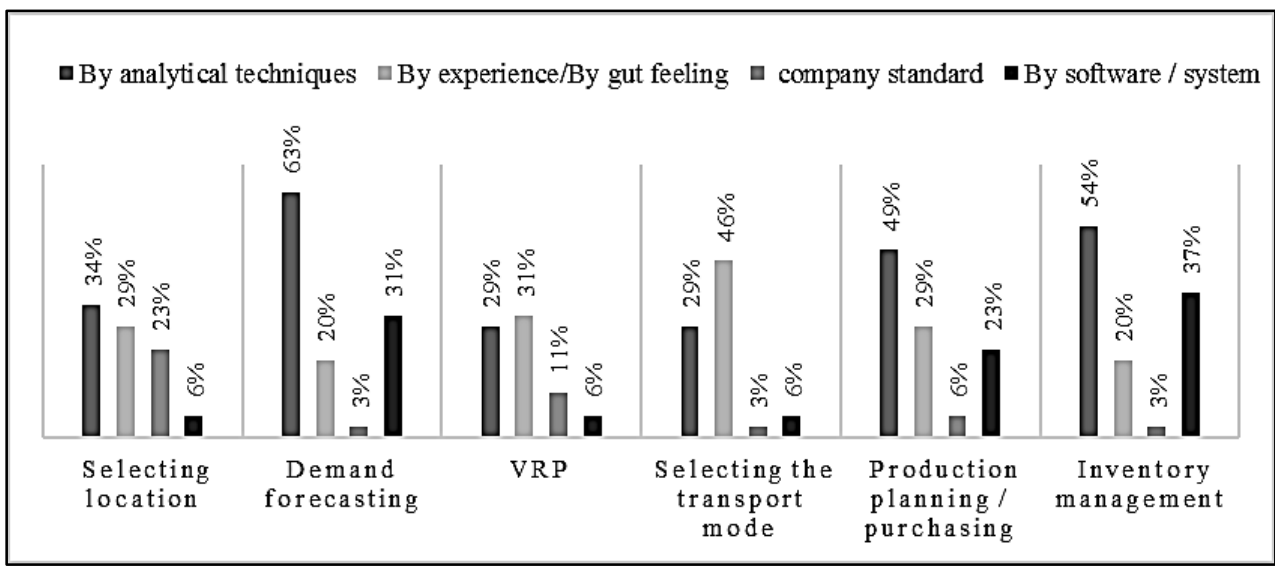

Figure 2: Decision Making Methods by Logistics Activities

The results of the Hierarchy Analysis performed using interview data, as illustrated in Figure 3, shows the frequency of different techniques used in the industry. Forecasting techniques such as moving averages, trend analysis and regression, inbuilt techniques, and the Gravity Model lead the use frequency. Respondents have identified they have started paying attention and using "Big Data" analytics, ML, and AI-related advanced techniques. 


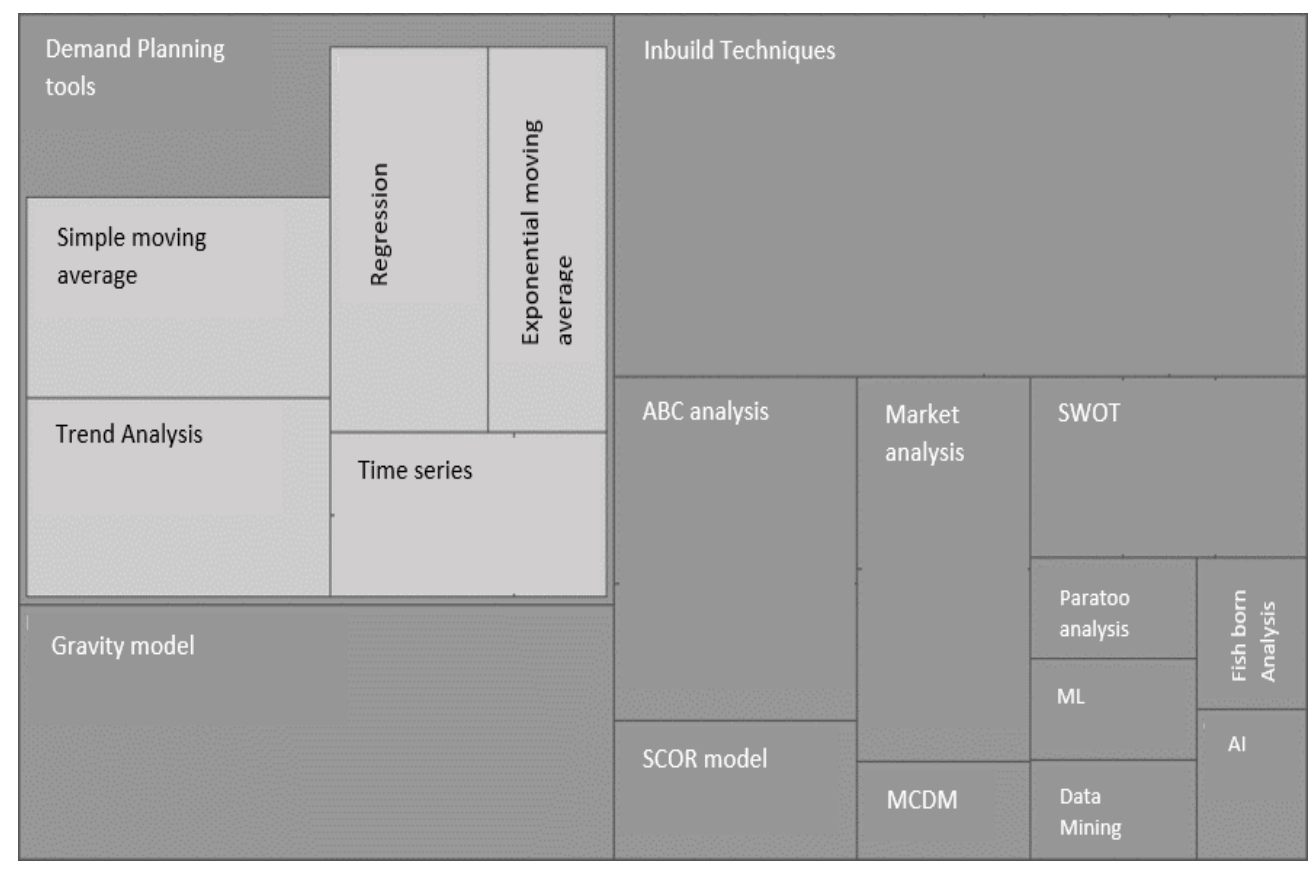

Figure 3: Hierarchy analysis for techniques used (using NVIVO software)

Moreover, Multinational Companies (MNCs) did not perform significantly different when compared to local companies in the use of ATs, with $37 \%$ of both types indicating they did not use AT regularly.

Table 9 shows that the Asymptotic Significance was higher than 0.05, which means that the $\mathrm{H}_{0}$ could not be rejected according to the Mann-Whitney test statistics. Therefore, it is concluded that there is no evidence to infer that the distributions of these two groups on the usage of ATs in making decisions on logistics management were not significantly different from each other.

Table 8: Mann-Whitney test - Ranks

\begin{tabular}{|c|c|c|c|c|}
\hline & Company Type & N & Mean Rank & Sum of Ranks \\
\hline \multirow{2}{*}{ Usage } & Local & 20 & 18.75 & 375.00 \\
\cline { 2 - 5 } & MNC & 17 & 19.29 & 328.00 \\
\cline { 2 - 5 } & Total & 37 & & \\
\hline
\end{tabular}


Table 9: Mann-Whitney test statistics

\begin{tabular}{|l|c|}
\hline & Usage \\
\hline Mann-Whitney U & 165.000 \\
\hline Wilcoxon W & 375.000 \\
\hline Z & -0.165 \\
\hline Asymp. Sig. (2-tailed) & 0.869 \\
\hline Exact Sig. [2*(1-tailed Sig.)] & $0.892^{\mathrm{b}}$ \\
\hline a. Grouping Variable: Company Type \\
\hline b. Not corrected for ties. \\
\hline
\end{tabular}

The analysis by type of company reveals that $25 \%$ of companies in apparel manufacturing use ATs regularly, compared to $16 \%$ in the FMCG industry, while $47 \%$ of the companies in the FMCG industry appeared to use AT, but less frequently (Figure 4).

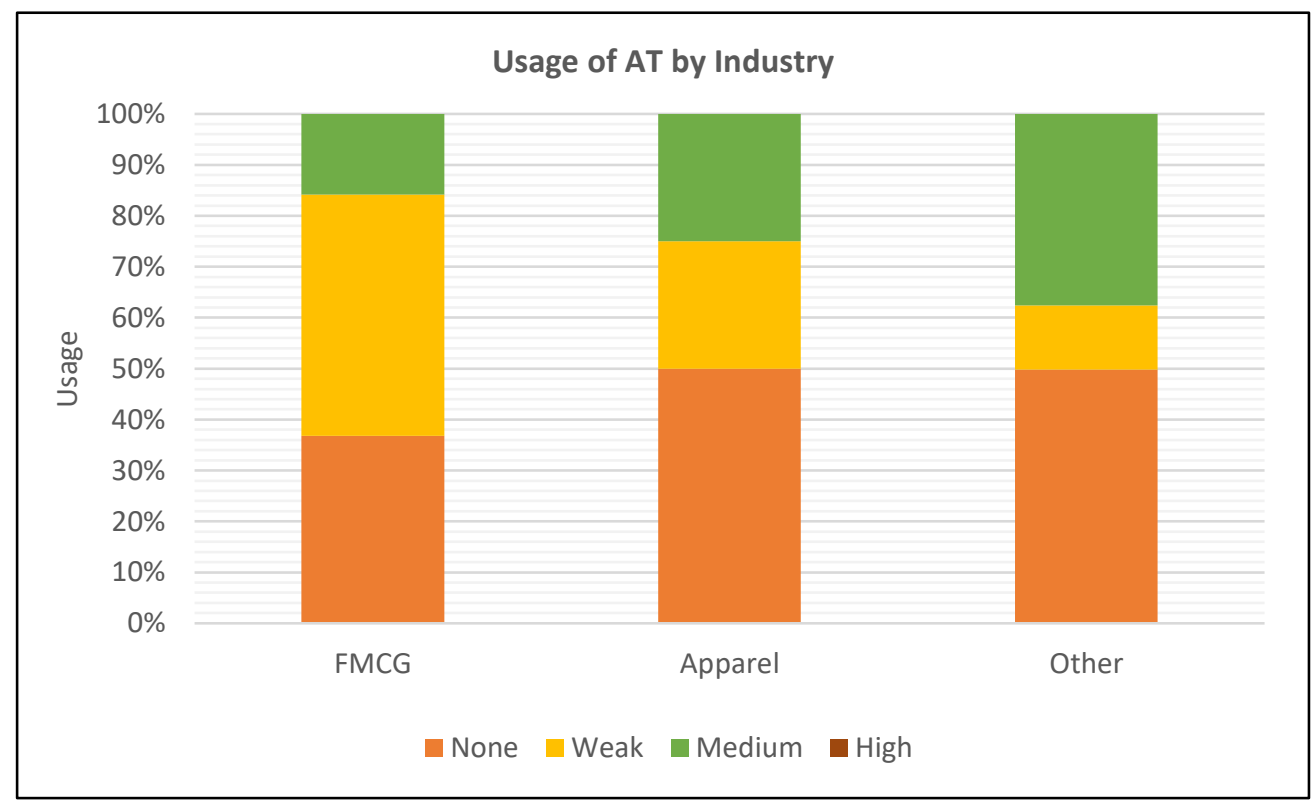

Figure 4: Usage of AT by industry

\subsection{Reasons for the reluctance to use ATs}

The use of Hierarchy analysis to identify the main reasons for the reluctance to use ATs yielded the key findings summarised in Figure 5. 


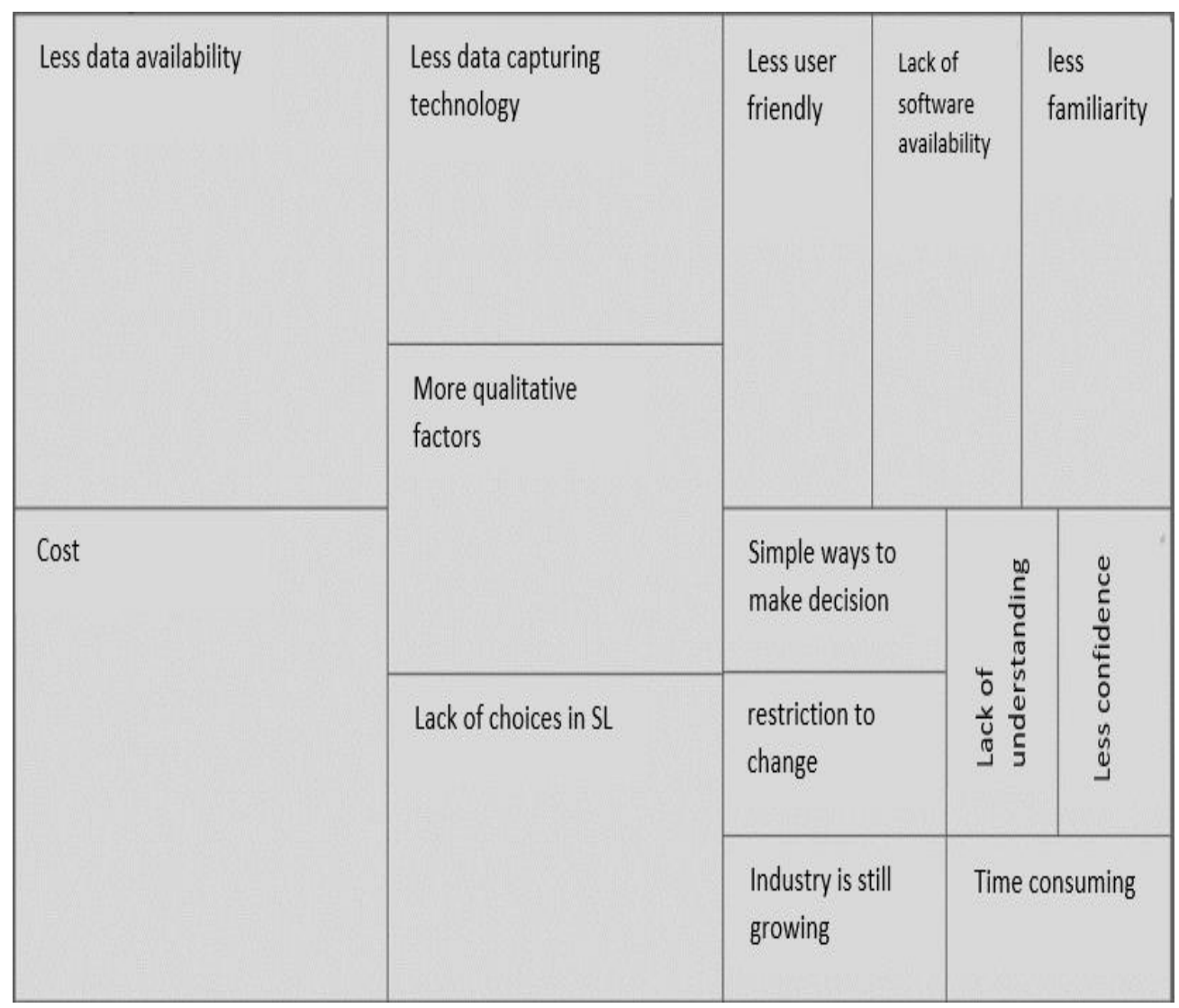

Figure 5: Hierarchy analysis for reluctance to use AT using NVIVO software

Data availability and costs appear to be the two main constraints inhibiting the use of quantitative techniques in the manufacturing sector of Sri Lanka. Data capturing technologies are not being effectively used in manufacturing industries, the reason being their lower attention on $R \& D$ in logistics decision making, compared to $R \& D$ on product development.

Among other reasons revealed through the interviews, the inadequate understanding of ATs, lack of familiarity and confidence, the intensity of time consumption, availability of simpler decision-making methods, low user-friendliness of AT, lack of expertise in the firms, and reluctance to change are found to be significant constraints in ATs being used in manufacturing industries.

\subsection{Industry requirements for increased use of ATs}

A descriptive analysis was performed using SPSS software on interview responses and the online questionnaire, identifying the prominent requirements for increased AT use in logistics decision-making in the Sri Lankan manufacturing sector. The results are summarised in Table 10. 
Table 10: Manufacturing Industry Requirements to achieve increased use of AT in Logistics

\begin{tabular}{|l|c|c|c|c|c|c|c|}
\hline \multicolumn{1}{|c|}{ Criteria } & N & Mean & $\begin{array}{c}\text { Std. } \\
\text { Deviation }\end{array}$ & \multicolumn{2}{|c|}{ Skewness } & \multicolumn{2}{c|}{ Kurtosis } \\
\cline { 2 - 8 } & Statistic & Statistic & Statistic & Statistic & $\begin{array}{c}\text { Std. } \\
\text { Error }\end{array}$ & Statistic & $\begin{array}{c}\text { Std. } \\
\text { Error }\end{array}$ \\
\hline $\begin{array}{l}\text { Flexibility (capability } \\
\text { of integrating side } \\
\text { constraints } \\
\text { encountered in real- } \\
\text { world applications) }\end{array}$ & 37 & 4.5405 & 0.60528 & -0.958 & 0.388 & -0.002 & 0.759 \\
\hline $\begin{array}{l}\text { Easy to use } \\
\text { Provides direct } \\
\text { solution }\end{array}$ & 37 & 4.2432 & 0.76031 & -0.449 & 0.388 & -1.105 & 0.759 \\
\hline $\begin{array}{l}\text { Time required to get } \\
\text { solutions using the } \\
\text { AT }\end{array}$ & 37 & 4.1892 & 0.81096 & -0.699 & 0.388 & -0.120 & 0.759 \\
\hline Accuracy of result & 37 & 4.1892 & 0.90792 & -1.338 & 0.388 & 2.644 & 0.759 \\
\hline $\begin{array}{l}\text { Availability of data } \\
\text { for AT }\end{array}$ & 37 & 3.8919 & 1.02154 & -0.434 & 0.388 & -0.960 & 0.759 \\
\hline $\begin{array}{l}\text { Software availability } \\
\text { Simplicity to use }\end{array}$ & 37 & 3.6757 & 0.97337 & -0.049 & 0.388 & -0.999 & 0.759 \\
\hline $\begin{array}{l}\text { Availability of } \\
\text { expertise to use } \\
\text { (training/technologies } \\
\text { etc.) }\end{array}$ & 37 & 3.4054 & 0.92675 & 0.403 & 0.388 & -0.607 & 0.759 \\
\hline Valid N (listwise) & 37 & 3.1351 & 1.22842 & -0.081 & 0.388 & -1.137 & 0.759 \\
\hline
\end{tabular}

All requirements identified and included in Table 10 as being significant, have mean values greater than 2.5 , which are presented in the descending order of their mean values, showing their relative prominence. Accordingly, "flexibility to integrate", particularly with inputs and outputs of other software and ERP systems, emerged as the most critical criterion. Ease of usage, ability to provide straightforward solutions, less time consumption and accuracy of results ranked high in the order of importance, while the simplicity of use, availability of expertise to use, and cost have also been identified as contributory criteria. 


\section{CONCLUSIONS AND RECOMMENDATIONS}

This paper focused on the use of ATs for manufacturing logistics optimisation by Sri Lankan manufacturing companies. It demonstrated that the use of such applications varied considerably across the logistics process and was mostly used for marketingoriented functions instead of operational or planning processes. The use of ATs also seemed to vary across different organisations, with the FMCG industry in the lead. However, compared to Sri Lankan companies, multinational companies did not indicate a significantly higher use of AT. Sri Lankan companies would stand to benefit by using advanced technologies in the manufacturing supply chain for planning through the effective capturing and analysing of data, improving the efficiency of operations, and thereby reducing costs. Yet, the use of ATs for logistics decision-making in the manufacturing industry in Sri Lanka was observed to be low, with low familiarity and availability being the primary constraints.

The industry gave several reasons for the inadequate use of ATs, led by cost considerations and data availability. Practical problems surrounding their familiarity and difficulties in applying them were cited as constraints. However, the interview results varied to some extent, indicating that AT use could be enhanced by making them more user-friendly, integrating to existing ERP solutions, and making them easier to use and providing answers that could be directly applied.

Thus, developing ATs for the logistics industry would require greater attention paid to enhance the flexibility of techniques and user-friendly software for convenient use by industrial establishments. Increasing R\&D in logistics operations could evolve better designs of AT solutions to meet these requirements.

\section{REFERENCES}

[1] M. Semini, "Applicability of Operations Research in Manufacturing Logistics," Norwegian University of Science and Technology, 2011.

[2] S. D. Wu, R. O. Roundy, R. H. Storer, and L. A. Martin-vega, "Manufacturing Logistics Research: Taxonomy and Directions," Tech. Rep. no. 99T-002, Dep. ISME, Lehigh Univ., pp. 1-24, 1999.

[3] M. Hesse, The city as a terminal: The urban context of logistics and freight transport. 2008.

[4] A. Aguezzoul, "Third-Party Logistics Selection Problem: A Literature Review on Criteria and Methods," Omega, 2014, DOI: 10.1016/j.omega.2014. 05.009. 
[5] B. Elevli, "Logistics freight center locations decision by using FuzzyPROMETHEE," Transport, vol. 29, no. 4, pp. 412-418, 2014, DOI: 10.3846/16484142.2014.983966.

[6] K. Govindan, R. Khodaverdi, and A. Vafadarnikjoo, "A grey DEMATEL approach to develop third-party logistics provider selection criteria," Ind. Manag. Data Syst., vol. 116, no. 4, 2016, [Online]. Available: http://dx.doi.org/10.1108/IMDS-05-2015-0180\%0ADownloaded.

[7] K. S. Moghaddam, "Fuzzy multi-objective model for supplier selection and order allocation in reverse logistics systems under supply and demand uncertainty," Expert Syst. Appl., vol. 42, no. 15-16, pp. 6237-6254, 2015, DOI: 10.1016/j.eswa.2015.02.010.

[8] U. R. Tuzkaya and S. Önüt, "A fuzzy analytic network process based approach to transportation-mode selection between Turkey and Germany: A case study," Inf. Sci. (Ny)., vol. 178, no. 15, pp. 3132-3145, 2008, DOI: 10.1016/j.ins.2008.03.015.

[9] N. Dabiri, M. J. Tarokh, and M. Alinaghian, "New mathematical model for the bi-objective inventory routing problem with a step cost function: A multiobjective particle swarm optimization solution approach," Appl. Math. Model., vol. 49, pp. 302-318, 2017, DOI: 10.1016/j.apm.2017.03.022.

[10] G. Ghiani, G. Laporte, and R. Musmanno, Introduction to Logistics Systems Planning and Control. John Wiley \& Sons, Ltd, 2005.

[11] G. Wang, A. Gunasekaran, E. W. T. Ngai, and T. Papadopoulos, "Big data analytics in logistics and supply chain management: Certain investigations for research and applications," Int. J. Prod. Econ., vol. 176, pp. 98-110, 2016, DOI: 10.1016/j.ijpe.2016.03.014.

[12] S. A. Alam and R. D. Jonsson, "Evaluation of the potential locations for logistics hubs: A case study for a logistics company," KTH Royal Institute of Technology, 2013.

[13] M. Alnahhal, M. I. Tabash, and D. Ahrens, "Optimal selection of third-party logistics providers using integer programming: a case study of a furniture company storage and distribution," Ann. Oper. Res., vol. 302, no. 1, pp. 1-22, 2021, DOI: 10.1007/s10479-021-04034-y.

[14] A. Alshamsi and A. Diabat, "A reverse logistics network design," J. Manuf. Syst., vol. 37, pp. 589-598, 2015, DOI: 10.1016/j.jmsy.2015.02.006. 
[15] P. Belfiore and H. T. Yoshida Yoshizaki, "Scatter search for a real-life heterogeneous fleet vehicle routing problem with time windows and split deliveries in Brazil," Eur. J. Oper. Res., vol. 199, no. 3, pp. 750-758, 2009, DOI: 10.1016/j.ejor.2008.08.003.

[16] G. Calabrò, V. Torrisi, G. Inturri, and M. Ignaccolo, "Improving inbound logistic planning for large-scale real-world routing problems: a novel antcolony simulation-based optimization," Eur. Transp. Res. Rev., vol. 12, no. 1, 2020, DOI: 10.1186/s12544-020-00409-7.

[17] M. Caramia and F. Guerriero, "A milk collection problem with incompatibility constraints," Interfaces (Providence)., vol. 40, no. 2, pp. 130143, 2010, DOI: 10.1287/inte.1090.0475.

[18] D. Çelebi, D. Bayraktar, and L. Bingöl, "Analytical Network Process for logistics management: A case study in a small electronic appliances manufacturer," Comput. Ind. Eng., vol. 58, no. 3, pp. 432-441, 2010, DOI: 10.1016/j.cie.2009.09.002.

[19] D. Chu, W. Ma, Z. Yang, J. Li, Y. Deng, and K. H. Cheong, "A Physaruminspired algorithm for logistics optimization: From the perspective of effective distance," Swarm Evol. Comput., vol. 64, no. June 2020, p. 100890, 2021, DOI: 10.1016/j.swevo.2021.100890.

[20] J.-P. Gagliardi, J. Renaud, and A. Ruiz, "Solving a real vehicle routing problem in the furniture and electronics industries," pp. 1-16, 2013, [Online]. Available: https://www.cirrelt.ca/DocumentsTravail/CIRRELT-FSA-201335.pdf.

[21] D. Galvez, A. Rakotondranaivo, L. Morel, M. Camargo, and M. Fick, "Reverse logistics network design for a biogas plant: An approach based on MILP optimization and Analytical Hierarchical Process (AHP)," J. Manuf. Syst., vol. 37, pp. 616-623, 2015, DOI: 10.1016/j.jmsy.2014.12.005.

[22] Z. Ghelichi, M. Gentili, and P. B. Mirchandani, "Logistics for a fleet of drones for medical item delivery: A case study for Louisville, KY," Comput. Oper. Res., vol. 135, no. June, p. 105443, 2021, DOI: 10.1016/j.cor.2021.105443.

[23] G. Kant, M. Jacks, and C. Aantjes, "Coca-Cola Enterprises optimizes vehicle routes for efficient product delivery," Interfaces (Providence)., vol. 38, no. 1, pp. 40-50, 2008, DOI: 10.1287/inte.1070.0331. 
[24] R. Lahyani, M. Khemakhem, and F. Semet, "Rich vehicle routing problems: From a taxonomy to a definition," Eur. J. Oper. Res., vol. 241, no. 1, pp. 114, 2015, DOI: 10.1016/j.ejor.2014.07.048.

[25] M. M. Paydar and M. Olfati, "Designing and solving a reverse logistics network for polyethylene terephthalate bottles," J. Clean. Prod., vol. 195, pp. 605-617, 2018, DOI: 10.1016/j.jclepro.2018.05.218.

[26] M. Rahbari, S. H. Razavi Hajiagha, M. Raeei Dehaghi, M. Moallem, and F. Riahi Dorcheh, "Modeling and solving a five-echelon location-inventoryrouting problem for red meat supply chain: Case study in Iran," Kybernetes, vol. 50, no. 1, pp. 66-99, 2021, DOI: 10.1108/K-10-2019-0652.

[27] Z. Turskis and E. K. Zavadskas, "A new fuzzy additive ratio assessment method (ARAS-F). Case study: The analysis of fuzzy multiple criteria in order to select the logistic centers location," Transport, vol. 25, no. 4, pp. 423-432, 2010, DOI: $10.3846 /$ transport.2010.52.

[28] G. H. Tzeng and C. Y. Huang, "Combined DEMATEL technique with hybrid MCDM methods for creating the aspired intelligent global manufacturing \& logistics systems," Ann. Oper. Res., vol. 197, no. 1, pp. 159-190, 2012, DOI: 10.1007/s10479-010-0829-4.

[29] J. G. Vidal Vieira, M. Ramos Toso, J. E. A. R. da Silva, and P. C. Cabral Ribeiro, "An AHP-based framework for logistics operations in distribution centres," Int. J. Prod. Econ., vol. 187, pp. 246-259, 2017, DOI: 10.1016/j.ijpe. 2017.03.001.

[30] Z. Wang, Y. Li, and X. Hu, "A heuristic approach and a tabu search for the heterogeneous multi-type fleet vehicle routing problem with time windows and an incompatible loading constraint," Comput. Ind. Eng., vol. 89, pp. 162176, 2015, DOI: 10.1016/j.cie.2014.11.004.

[31] E. E. Zachariadis, C. D. Tarantilis, and C. T. Kiranoudis, "The pallet-packing vehicle routing problem," Transp. Sci., vol. 46, no. 3, 2012, DOI: 10.1287/trsc .1110 .0373 .

[32] N. Zarbakhshnia, Y. Wu, K. Govindan, and H. Soleimani, "A novel hybrid multiple attribute decision-making approach for outsourcing sustainable reverse logistics," J. Clean. Prod., vol. 242, p. 118461, 2020, DOI: 10.1016 /j.jclepro.2019.118461. 
[33] M. Woschank, E. Rauch, and H. Zsifkovits, "A review of further directions for artificial intelligence, machine learning, and deep learning in smart logistics," Sustain., vol. 12, no. 9, 2020, DOI: 10.3390/su12093760.

[34] R. Handfield, F. Straube, H.-C. Pfohl, and A. Wieland, Trends and strategies in logistics and supply chain management. 2013.

[35] Z. Yan, H. Ismail, L. Chen, X. Zhao, and L. Wang, "The application of big data analytics in optimizing logistics: a developmental perspective review," $J$. Data, Inf. Manag., vol. 1, no. 1-2, pp. 33-43, 2019, DOI: 10.1007/s42488019-00003-0. 